\title{
The Commitment Curve: Global Regulation of Business and Human Rights - ERRATUM
}

\author{
Tori Loven KIRKEB $\varnothing$ and Malcolm LANGFORD
}

doi: 10.1017/bhj.2018.11, Published by Cambridge University Press, 11 September 2018

During typesetting of the above published scholarly article reference 84 was inadvertently removed. The reference should have been:

84 IFOAM (2016) 'IFOAM Standard', http://www.ifoam.bio/en/ifoam-standard (accessed 3 March 2016).

Cambridge University Press apologises for this error.

\section{REFERENCE}

KIRKEBØ, T., \& LANGFORD M., (2018). The Commitment Curve: Global Regulation of Business and Human Rights. Business and Human Rights Journal, 3(2), 157-185. doi:10.1017/bhj.2018.11 